\title{
Diagnóstico y tipificación del virus de la leucosis bovina mediante una prueba de PCR-RFLP a partir de ADN extraído desde células somáticas de la leche\#
}

\author{
Diagnosis and typing of bovine leukaemia virus using a PCR-RFLP test on DNA \\ extracted from somatic cells in milk \\ R Felmer*, J Zúñiga, M Recabal, R Chávez \\ Laboratorio de Biotecnología Animal, Unidad de Biotecnología, INIA-Carillanca, Temuco, Chile.
}

\begin{abstract}
SUMMARY
The aim of this study was to assess the suitability of using DNA isolated from milk somatic cells for the diagnosis and molecular typing of bovine leukaemia virus (BLV). A total of 40 bulk milk samples were analysed and thirty three of them resulted seropositive to BLV after being evaluated using an indirect ELISA test. A PCR test confirmed the presence of the virus in all 33 seropositive samples whereas in the remaining seronegative samples it was not possible to detect a specific band for the virus. A RFLP analysis identified 2 out of the 3 known subgroups of BLV genetic variants. Individual analysis carried out in the PCR positive herd confirmed the presence of more than one genetic variant within this herd, suggesting that there is a possibility of re-infection occurring with another virus strain. This report is the first to describe the application of a PCRRFLP test for the detection and molecular typing of BLV directly from milk samples. The simplicity of collecting bulk milk samples makes the described technique a convenient way for a quick diagnosis of the virus, which can also be used to study the molecular epidemiology and distribution of BLV infection in a specific area or even at national scale.
\end{abstract}

Palabras clave: PCR, leucosis, RFLP, electroforesis.

Key words: PCR, leukaemia, RFLP, electrophoresis.

\section{INTRODUCCION}

La leucosis enzoótica bovina es una enfermedad neoplásica del sistema retículo endotelial del ganado causada por la infección con el virus de la leucosis bovina (VLB), un retrovirus de la familia Retroviridae (Kettmann y col 1976, Radostits y col 1995). Estudios genéticos han demostrado una escasa variación en este virus con respecto a otros de la familia Retroviridae, representados principalmente por los lentivirus (Willems y col 1993, Mansky 1998). Sin embargo, la importancia de estudiar la variabilidad genética de este y otros virus en general radica en que permite monitorear la aparición de nuevas variantes genéticas y mantener una vigilancia constante, a nivel molecular del genoma del virus, en busca de cepas mutantes que puedan surgir en la naturaleza y que posean la capacidad de infectar al hombre. Entre los motivos que justifican esta preocupación, se puede mencionar la capacidad del virus de infectar in vitro células de distintas especies animales, incluyendo al hombre (Dahlberg 1988). En forma adicional, la información de la variabilidad genética de un virus permite realizar es-

Aceptado: 23.03.2006.

\# Financiado por Proyecto FIA BID-PI-C-2001-1-P-035.

* Casilla 58-D, Temuco, Fono: 45-215706, Fax: 45-216112; rfelmer@inia.cl tudios epidemiológicos y construir árboles filogenéticos para trazar el origen del virus (Belak y Thoren 2001). En 1981, Kettmann y col estudiaron las secuencias nucleotídicas de diferentes aislados del VLB y encontraron sitios de restricción en el genoma que permitían clasificar a estos aislados en 3 principales sub-grupos: europeo, australiano y norteamericano-japonés. Esta información fue posteriormente confirmada mediante la secuenciación de 3 aislados provenientes de Bélgica, Japón y Australia, corroborando la factibilidad de utilizar una prueba de RFLP (restriction fragment length polymorphism) para clasificar a este virus y estudiar la distribución de la infección en los rebaños (Coulston y col 1990). Este mismo análisis, aunque ahora mediante PCR-RFLP, está siendo utilizado por diversos autores para estudiar la diversidad genética de VLB (Fechner y col 1997, Beier y col 2001, Licursi y col 2002, Zaghawa y col 2002, Limanskii y col 2004). En todos estos casos el ADN viral ha sido detectado mediante PCR a partir de la fracción de linfocitos sanguíneos.

Dado que la recolección de muestras de sangre es laboriosa y requiere un grado mayor de logística (personal entrenado, visitas a terreno, etc.), el objetivo del presente estudio fue evaluar la factibilidad de emplear muestras de leche, con énfasis en la utilización de leche del estanque predial, para diagnosticar y tipificar el VLB. La ventaja de este enfoque es que permitiría no sólo apoyar al diagnóstico complementario del VLB, sino 
además realizar la tipificación del virus en forma rápida y conveniente para así estudiar la epidemiología y distribución de la infección en una amplia zona geográfica, incluso a nivel de país.

\section{MATERIAL Y METODOS}

Obtención de las muestras y procesamiento. Se obtuvieron muestras de leche del estanque predial directamente desde nuestro Laboratorio de Calidad de Leche de INIACarillanca, Temuco, y correspondieron a muestras de diferentes predios de la IX Región. Muestras de leche de animales individuales se obtuvieron de un predio lechero de la comuna de Freire, con historial clínico de leucosis. Las muestras se procesaron eliminándoles la crema mediante centrifugación por 10 minutos a 3.500 r.p.m. La fracción clarificada se conservó a $-20^{\circ} \mathrm{C}$ para su posterior análisis de anticuerpos mediante ELISA, mientras que la fracción de células somáticas se conservó a $-20^{\circ} \mathrm{C}$ hasta el momento de la extracción de ADN.

Aislamiento de $A D N$. La fracción de células somáticas correspondiente a $60 \mathrm{ml}$ de leche se utilizó para la extracción de $\mathrm{ADN}$, de acuerdo a un protocolo estándar que consistió de una lisis celular a $55^{\circ} \mathrm{C}$ durante la noche en un tampón conteniendo Proteinasa K (Tris- $\mathrm{HCl}$, 10 mM pH 8,0; EDTA 1 mM, Proteinasa K 1 mg/ml y SDS 1\%). Los restos celulares se precipitaron y separaron mediante la adición de $\mathrm{NaCl} 5 \mathrm{M}$ y centrifugación a máxima velocidad por 10 minutos. El ADN se recuperó finalmente de la fase acuosa mediante precipitación con etanol y se resuspendió en tampón T.E.

Análisis serológico. La detección de anticuerpos contra el VLB en las muestras de leche se realizó mediante la técnica de enzimoinmuno ensayo indirecto (ELISA-i) empleando un kit comercial (SVANOVA, Suecia) de acuerdo a las instrucciones del fabricante. Las lecturas espectrofotométricas se realizaron en un lector ELISA (Labsystems, Multiskan EX) a $450 \mathrm{~nm}$ y utilizando para la interpretación de los resultados una relación de densidad óptica corregida (DO muestra/DO control positivo) igual o superior a $6 \%$.

Análisis molecular mediante PCR-RFLP. El diagnóstico del virus se realizó mediante PCR anidado utilizando partidores correspondientes a una región altamente conservada del gen env viral (para detalles ver Beier y col 2001). La aparición de una banda de amplificación de 444 pb se consideró como confirmatoria de la presencia del VLB. Para la tipificación molecular del virus mediante RFLP se utilizaron $10 \mu \mathrm{l}$ de producto de PCR, el que se digirió con $5 \mathrm{U}$ de cada de las enzimas de restricción Bam HI, $P v u$ II y $B c l$ I. Los productos de PCR y fragmentos de restricción fueron visualizados en geles de agarosa al 3\% teñidos con bromuro de etidio $(0,5 \mu \mathrm{g} / \mathrm{ml})$.

\section{RESULTADOS Y DISCUSION}

Para realizar la detección y posterior tipificación de VLB, mediante la prueba de PCR-RFLP, se seleccionaron 40 muestras de leche de estanques prediales correspondientes a diferentes predios de la IX Región. De estas muestras, 33 fueron clasificadas como seropositivas mediante una prueba de ELISA, mientras que las restantes fueron clasificadas como negativas. El PCR permitió confirmar la presencia del virus en las 33 muestras seropositivas, mientras que en las muestras seronegativas no se obtuvo una banda de amplificación (figura 1). Este resultado permitió confirmar la factibilidad de detectar el virus directamente desde las muestras de leche del estanque predial, permitiendo realizar por primera vez la tipificación del virus mediante la prueba de RFLP a partir de estas muestras. El análisis mediante RFLP permitió asignar los productos de PCR a 2 de los 3 subgrupos de variantes genéticas descritas de VLB. La enzima Bam HI digirió el fragmento de PCR en 17 de las 33 muestras analizadas, obteniéndose un perfil de restricción similar al esperado para el subgrupo Belga (Rice y col 1984), resultando en fragmentos de 326 y 128 pb, respectivamente (figura 2). Las 16 muestras que no fueron digeridas por Bam HI fueron en cambio digeridas por la enzima $P v u$ II, confirmando un perfil de restricción similar al esperado para el subgrupo australiano (Coulston y col 1990), resultando en fragmentos de 280 y 164 pb, respectivamente. En ninguna de las muestras analizadas se obtuvo un perfil similar al del subgrupo japonés (Sagata y col 1985), ya que la digestión con la enzima de restricción $\mathrm{Bcl}$ I generó una banda doble de 220 y 225 pb en las 33 muestras analizadas. Estos hallazgos demuestran la presencia en nuestra Región de 2 de las 3 variantes genéticas de VLB descritas en el mundo. No se encontraron variantes genéticas correspondientes al subgrupo japonés, lo que refleja probablemente las prácticas de comercio animal realizadas en nuestro país en décadas pasadas, principalmente con países de Norteamérica y Europa, lugares donde existe una mayor concentración de estas variantes genéticas del virus. Aunque no podemos descartar la posibilidad de encontrar alguna variante genética similar al subgrupo japonés en un estudio más ampliado.

Esta misma prueba se evaluó, además, a nivel individual, seleccionando para ello muestras de leche de 10 animales de un predio con historial clínico de leucosis. El producto de amplificación de estas muestras fue digerido con un mayor número de enzimas de restricción, para aumentar el poder resolutivo de la técnica. De esta forma, adicionalmente a las enzimas Bam HI, $P v u$ II y $B c l$ I del estudio anterior, se incluyeron las enzimas $A v a$ I, Psy I, Taq I, Acc I, $B g l$ I, y $C v i$ II. Como se observa en la figura 3, no se encontraron diferencias en los perfiles de restricción al analizar las muestras con las enzimas Psy I, Taq I, Acc I, Bcl I, Bgl I y Cvi II, ya que los 


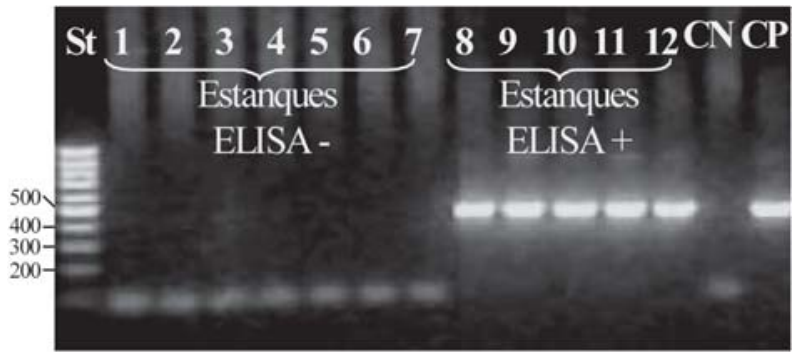

Figura 1. Amplificación mediante PCR del ADN viral extraído desde linfocitos de la leche del estanque predial.

Electroforesis en agarosa al 1,5\% de productos de PCR de muestras de leche de estanques prediales seronegativas (1-7) y seropositivas (8-12) a una prueba de ELISA indirecto.

St: Estándar $1 \mathrm{~Kb}$ (Promega); CN: control negativo; CP: control positivo, fragmento de $444 \mathrm{pb}$ del gen env de VLB clonado en el plasmido TOPO-TA vector (Invitrogen).

PCR amplification of viral DNA extracted from milk lynphocytes contained in bulk milk.

$1.5 \%$ agarose gel electrophoresis of PCR products in seronegative (17) and seropositve (8-12) bulk milk samples by an indirect ELISA test. St: Standard, $1 \mathrm{~Kb}$ (Promega); CN: Negative Control; CP: Positive Control, 444 bp env fragment of BLV cloned into TOPO-TA vector (Invitrogen).

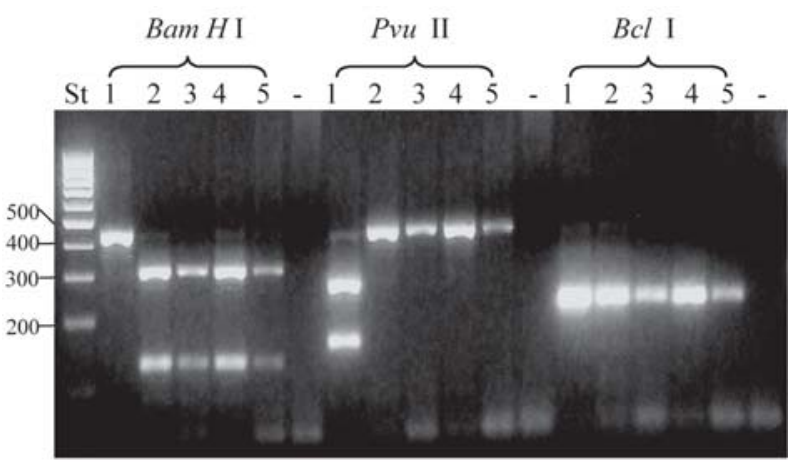

Figura 2. Análisis RFLP de muestras de ADN viral amplificadas desde linfocitos de la leche del estanque predial.

Electroforesis en agarosa al 3\% de productos de PCR digeridos con las enzimas de restricción Bam HI, $P v u$ II y $B c l$ I, respectivamente. Carriles 1-5 corresponden a 5 diferentes muestras de estanque predial. St: corresponde al estándar de tamaño molecular $1 \mathrm{~Kb}$ (Promega); -: Muestra control de un predio negativo al VLB.

Restriction fragment length polymorphism (RFLP) analysis of amplified viral DNA samples from milk, lynphocytes contained in bulk milk.

3\% agarose gel electrophoresis of PCR amplicons digested with Bam HI, $P v u$ II and $B c l$ I, respectively. Lanes 1-5 correspond to 5 different herd's bulk milk samples. St: Standard $1 \mathrm{~Kb}$; -: Negative herd sample.

fragmentos generados fueron similares para todas las muestras analizadas. Sin embargo, las enzimas de restricción Ava I, Bam HI y Pvu II permitieron identificar dos variantes genéticas de este virus en el predio, ya que el perfil de restricción de las muestras 1 y 2 fue diferente al de las muestras 3, 4 y 5 . De acuerdo a los resultados

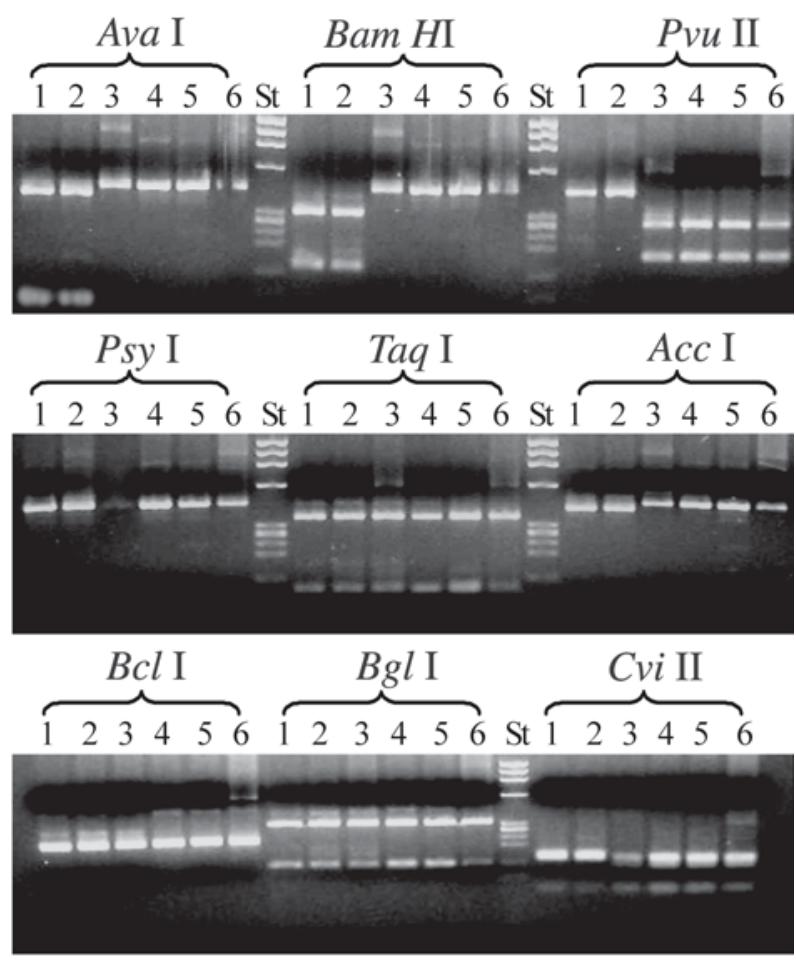

Figura 3. Análisis RFLP de muestras de ADN viral amplificadas desde células somáticas de la leche de animales individuales.

Electroforesis en agarosa al 3\% de los productos de amplificación de 6 diferentes muestras de animales individuales (1-6) digeridas con las enzimas de restricción como se muestra en la Figura. St: Standard $1 \mathrm{~Kb}$ (Promega).

Restriction fragment lenght polymorphism (RFLP) analysis of amplified viral DNA samples from milk leukocytes of individual animals.

$3 \%$ agarose gel electrophoresis of PCR amplicons of 6 individual samples of different cows (1-6) digested with restriction enzymes as shown in the Figure. St: Standard $1 \mathrm{~Kb}$ (Promega).

obtenidos con las enzimas de restricción Bam HI y $P v u$ II, este predio tendría las dos variantes genéticas descritas anteriormente, es decir, las variantes genéticas correspondientes al subgrupo belga y australiano. Además, es interesante destacar que una nueva enzima de restricción incluida en el análisis (Ava I), también permitiría distinguir a estas dos variantes genéticas, lo que ampliaría el repertorio de enzimas disponibles para estudiar la diversidad genética del virus. Este análisis permite concluir la presencia de más de una variante genética o cepa de este virus en el predio analizado, situación que refleja más probablemente una reinfección del predio con otra cepa del virus. Eventualmente, la presencia de estas dos cepas en el mismo predio podría deberse a una mutación del virus, aunque menos probable, a nuestro entender, debido a la baja tasa de mutación descrita para este virus, que no supera el 0,0009\% (cambios nucleotídicos por ciclo de replicación por año; Willems y col 1993). Este resultado resalta la importancia en la implementación 
de medidas de bioseguridad en un predio para evitar así la infección o reintroducción de un virus en particular.

En un estudio preliminar (datos no publicados) evaluamos este método de PCR en muestras individuales de leche y sangre de animales seropositivos a la prueba de ELISA. El PCR en leche fue positivo solo para el $41 \%$ de las muestras que dieron positivas al PCR en sangre. Esta baja correlación entre ambas muestras se explica fundamentalmente por el menor número de linfocitos B, la célula blanco por elección, presentes en la muestra de leche (Mirsky y col 1996). Otros factores que pueden interferir con la capacidad de detección del virus en leche tienen que ver con el período de lactancia del animal, debido a que los niveles de células somáticas y linfocitos varían durante la lactancia (Asai y col 1998), así como también varían debido a factores ambientales como la mastitis. En este estudio preliminar encontramos, no obstante, una buena correlación (100\%) entre ELISA y PCR aplicados a muestras de leche de estanques prediales. Esto se explicaría por la mayor probabilidad que en un rebaño exista más de un animal infectado que contribuya con una mayor carga de linfocitos infectados al estanque predial.

Debido a la facilidad en la recolección de la muestra del estanque predial, la gran utilidad de esta técnica estaría en la posibilidad de realizar estudios epidemiológicos del virus en una forma rápida y conveniente. El estudio de la diversidad genética del VLB y de cualquier virus en general es importante, porque permite no sólo monitorear la aparición de nuevas variantes genéticas, sino además permite trazar el movimiento de animales (introducción de nuevas cepas desde otros predios o incluso países vecinos) y subtipificar el virus para estudios epidemiológicos. Además, el PCR puede detectar variantes genéticas del VLB que no reaccionan con anticuerpos en pruebas serológicas de rutina (Fechner y col 1997, Beier y col 1998).

En conclusión, la técnica de PCR que aplicamos en forma pionera a muestras de leche del estanque predial, podría ser de utilidad no solo como complemento al diagnóstico del VLB, sino también como una forma conveniente de realizar la tipificación del virus en una zona determinada o incluso a nivel de país, lo cual proporciona una forma rápida y conveniente de entender la epidemiología y distribución de la infección del VLB en nuestros rebaños.

\section{RESUMEN}

Se evaluó la factibilidad de aplicar una prueba de PCR para el diagnóstico y tipificación molecular del virus de la leucosis enzoótica bovina (VLB), directamente desde muestras de leche. Se analizó un total de 40 muestras de estanque predial, 33 de las cuales fueron seropositivas a una prueba de ELISA. El PCR confirmó la presencia del virus en el $100 \%$ de los estanques seropositivos, mientras que en las muestras seronegativas no se obtuvo una banda de amplificación. El posterior análisis de estas muestras mediante RFLP permitió identificar la presencia de 2 de los 3 subgrupos conocidos de variantes genéticas del virus. La aplicación de esta prueba en 10 animales de un predio permitió confirmar la presencia de más de una variante genética dentro del mismo predio, sugiriendo la probable reinfección de este predio con otras cepas del virus. Es necesario destacar que este trabajo constituye el primer reporte de la aplicación de una prueba de PCR-RFLP para la detección y tipificación del VLB directamente desde muestras de leche. De esta forma, la técnica de PCR descrita se puede utilizar no sólo como complemento al diagnóstico del VLB, sino también como una forma conveniente de realizar la tipificación del virus en una zona determinada o incluso a nivel de país, lo cual proporciona una forma rápida y conveniente de estudiar la epidemiología y distribución de la infección del VLB en nuestros rebaños.

\section{AGRADECIMIENTOS}

Este trabajo fue financiado por la Fundación para la Innovación Agraria (FIA), Programa de Biotecnología, Ministerio de Agricultura, Chile (Proyecto BID-PI-C-2001-1- P-035). Los autores agradecen, además, la colaboración del Laboratorio de Calidad de Leche de INIACarillanca y de los productores lecheros de la IX Región por facilitar el muestreo de sus animales y estanques prediales.

\section{REFERENCIAS}

Agresti A, W Ponti, M Rocchi, R Meneveri, A Marozzi, D Cavalleri, E Peri, G Poli, E Ginelli. 1993. Use of polymerase chain reaction to diagnose bovine leukemia virus infection in calves at birth. Am $J$ Vet Res 3, 373-8.

Asai K, K Kai, H Rikiishi, S Sugawara, Y Maruyama, T Yamaguchi, M Ohta, K Kumagai. 1998. Variation in CD4+ T and CD8+ T lymphocyte subpopulations in bovine mammary gland secretions during lactating and non-lactating periods. Vet Immunol Immunopathol 161, 51-61.

Beier D, P Blankenstein, H Fechner. 1998. Possibilities and limitations for use of the polymerase chain reaction (PCR) in the diagnosis of bovine leukaemia virus (BLV) infection in cattle. Dtsch. Tierarztl Wochenschr 11, 408-12.

Beier D, P Blankenstein, O Marquardt, J Kuzmak. 2001. Identification of different BLV proviruses isolates by PCR, RFLP and DNA sequencing. Berl. Münch. Tieräztl Wschr 114, 252-256.

Belak S, P Thoren. 2001. Molecular diagnosis of animal diseases: some experiences over the past decade. Expert. Rev Mol Diagn 4, 434-43.

Burridge M, M Thurmond, J Miller, M Schmerr, M Van Der Maaten. 1982. Duration of colostral antibodies to bovine leukemia virus by two serologic tests. Am J Vet Res 10, 1866-7.

Coulston J, H Naif, R Brandon, S Kumar, S Khan, R Daniel, M Lavin. 1990. Molecular cloning and sequencing of an Australian isolate of proviral bovine leukaemia virus DNA: comparison with other isolates. J Gen Virol 71, 1737-46.

Dahlberg J. 1988. An overview of retrovirus replication and classification. Adv Vet Sci Comp Med 32, 1-35.

Evermann J, M Jackson. 1997. Laboratory diagnostic tests for retroviral infections in dairy and beef cattle. Vet Clin North Am Food Anim Pract 1, 87-106.

Fechner H, A Kurg, L Geue, P Blankenstein, G Mewes, D Ebner, D Beier. 1996. Evaluation of polymerase chain reaction (PCR) application in diagnosis of bovine leukaemia virus (BLV) infection in naturally infected cattle. Zentralbl Veterinarmed B 10, 621-30.

Fechner H, P Blankenstein, A Looman, J Elwert, L Geue, C Albrecht, A Kurg, D Beier, O Marquardt, D Ebner. 1997. Provirus variants of the bovine leukemia virus and their relation to the serological status of naturally infected cattle. Virology 237, 261-9.

Kelly E, M Jackson, G Marsolais, J Morrey, R Callan. 1993. Early detection of bovine leukemia virus in cattle by use of the polymerase chain reaction. Am J Vet Res 2, 205-9. 
Klintevall K, A Ballagi-Pordany, K Naslund, S Belak. 1994. Bovine leukaemia virus: rapid detection of proviral DNA by nested PCR in blood and organs of experimentally infected calves. Vet Microbiol 3, 191-204.

Kettmann R, D Couez, A Burny. 1981. Restriction endonuclease mapping of linear unintegrated proviral DNA of bovine leukemia virus. $J$ Virol 38, 27-33.

Kuckleburg C, C Chase, E Nelson, S Marras, M Dammen, J Christopher-Hennings. 2003. Detection of bovine leukemia virus in blood and milk by nested and real-time polymerase chain reactions. $J$ Vet Diagn Invest 1, 72-6.

Licursi M, Y Inoshima, D Wu, T Yokoyama, E Gonzalez, H Sentsui. 2002. Genetic heterogeneity among bovine leukemia virus genotypes and its relation to humoral responses in hosts. Virus Res 1, 101-10.

Limanskii A, L Geue, O Limanskaia, D Beier. 2004. Typing of cattle leukemia virus circulating in the Ukraine. Vopr Virusol 1, 39-44.

Mamoun R, M Morisson, N Rebeyrotte, B Busetta, D Couez, R Kettmann, M Hospital, B Guillemain. 1990. Sequence variability of bovine leukemia virus env gene and its relevance to the structure and antigenicity of the glycoproteins. J Virol 64, 4180-8.
Mirsky M, C Olmstead, Y Da, H Lewin. 1996. The prevalence of proviral bovine leukemia virus in peripheral blood mononuclear cells at two subclinical stages of infection. J Virol 4, 2178-83.

Radostits O, D Blood, C Gay. 1995. Enzootic-bovine leukosis (bovine lymphosarcoma). En: Radostits O, Blood D and Gay C (eds), Veterinary Medicine, $8^{\text {th }}$ Edn Bailliere Tindall, London, Pp 954-965.

Reichert M, J Stec. 1999. Simultaneous use of two primer pairs increases the efficiency of polymerase chain reaction assay in the diagnosis of bovine leukemia virus. J Vet Diagn Investig 11, 543-547.

Sagata N, T Yasunaga, J Tsuzuku-Kawamura, K Ohishi, Y Ogawa, Y Ikawa. 1985. Complete nucleotide sequence of the genome of bovine leukemia virus: its evolutionary relationship to other retroviruses. Proc Natl Acad Sci USA 82, 677-81.

Willems L, E Thienpont, P Kerkhofs, A Burny, M Mammerickx, R Kettmann. 1993. Bovine leukemia virus, an animal model for the study of intrastrain variability. J Virol 67, 1086-9.

Zaghawa A, D Beier, I El-Rahim, I Karim, S El-ballal, F Conraths, O Marquardt. 2002. An outbreak of enzootic bovine leukaemia in upper Egypt: clinical, laboratory and molecular-epidemiological studies. J Vet Med 49, 123-9. 